\title{
MENINGKATKAN HASIL BELAJAR SISWA MATA PELAJARAN BAHASA INDONESIA MELALUI MODEL EXAMPLE NON EXAMPLE DI KELAS VI SD NEGERI NO 053979 KEPALA SUNGAI
}

\author{
Ramelan \\ Surel: ramelanlan789@gmail.com
}

\begin{abstract}
ABSTRAK
Tujuan penelitian ini adalah untuk meningkatkan hasil belajar siswa pada mata pelajaran Bahasa Indonesia. Tes hasil belajar I diperoleh dari 26 orang siswa yang menjadi subjek dalam penelitian ini, ternyata hanya 17 orang siswa $(62,96 \%)$ yang sudah memiliki ketuntasan belajar, sedangkan 10 orang siswa $(37,04 \%)$ belum memiliki ketuntasan belajar. Nilai rata - rata diperoleh mencapai 68,4. Pada siklus II kemudian diperoleh 24 orang siswa $(88,88 \%)$ sudah memiliki ketuntasan belajar, sedangkan 3 orang siswa $(11,12 \%)$ belum memiliki ketuntasan belajar. Nilai rata - rata yang diperoleh mencapai 81,19. Berdasarkan hal ini, maka diperoleh kesimpulan dalam penelitian ini adalah "Terdapat Peningkatkan Hasil Belajar Siswa Pada Mata Pelajaran Bahasa Indonesia Melalui Model Pembelajaran Example Non Example di VI SD Negeri No 053979 Kepala Sungai T.A. 2016/2017".
\end{abstract}

Kata Kunci : Bahasa Indonesia, Hasil Belajar, Example non Example.

\section{PENDAHULUAN}

Pendidikan di Sekolah Dasar

(SD) bertujuan memberikan bekal kemampuan dasar calistung (baca tulis hitung), pengetahuan dan keterampilan dasar yang bermanfaat bagi siswa yang sesuai dengan tingkat perkembangannya serta mempersiapkan mereka untuk mengikuti pendidikan yang lebih tinggi. Terkait dengan tujuan memberikan bekal kemampuan dasar "baca tulis" maka peranan pengajaran Bahasa Indonesia di SD menjadi sangat penting. Pembelajaran Bahasa Indonesia tidak hanya pada tahap keberwacanan (di kelas I dan kelas II) tetapi juga pada tercapainya kemahiran wacanan (di kelas-kelas tinggi atau kelas III sampai kelas VI $\mathrm{SD})$.

Hakikatnya belajar bahasa adalah belajar komunikasi, oleh sebab itu pembelajaran Bahasa Indonesia diarahkan untuk meningkatkan keterampilan siswa dalam berkomunikasi dengan bahasa yang baik dan benar, baik secara lisan maupun tertulis

Bahasa merupakan salah satu hasil kebudayaan yang harus dipelajari dan diajarkan. Dengan bahasa kebudayaan suatu bangsa dapat dibentuk, dibina, dan dikembangkan serta dapat diturunkan kepada generasi-generasi mendatang. Bahasa memungkinkan manusia dapat memikirkan suatu masalah secara 
teratur, terus-menerus, dan berkelanjutan. Sebaliknya, tanpa bahasa peradaban manusia tidak mungkin dapat berkembang baik. Pengajaran bahasa Indonesia pada hakikatnya merupakan salah satu sarana mengupayakan pembinaan dan pengembangan bahasa Indonesia secara terarah. Maka dari itu melalui proses pengajaran bahasa Indonesia diharapkan siswa mempunyai kemampuan yang memadai untuk dapat menggunakan bahasa Indonesia secara baik dan benar.

Pada hakikatnya tujuan
pembelajaran bahasa dan sastra
Indonesia disekolah adalah untuk
mengembangkan keterampilan
berbahasa baik lisan maupun tulisan.
Keterampilan berbahasa yang
dimaksud adalah tidak lain yaitu
keterampilan menyimak, berbicara,
membaca dan menulis. Dengan kata
lain bahwa pembelajaran bahasa
diarahkan pada pembinaan
keterampilan berkomunikasi dalam
berbagai situasi.

Bahasa

sebagai alat komunikasi digunakan dalam bermacam-macam fungsi bahasa sesuai dengan yang ingin disampaikan oleh pemakai bahasa. Oleh karena itu, maka pengajaran bahasa Indonesia harus diarahkan pada kemampuan berkomunikasi dalam kontek penggunaan bahasa. Faktor-faktor penentu berkomunikasi, yaitu (1) siapa yang berbicara dengan siapa; (2) untuk tujuan apa; (3) dalam situasi apa; (4) dalam konteks apa (peserta lain, kebudayaan dan suasana); (5) dengan jalur apa (lisan atau tulisan); (6) media apa (tatap muka, telepon, surat, buku surat kabar); dan (7) dalam peristiwa apa (bercakap-cakap, cerama, laporan, upacara, lamaran kerja, dll.

Dalam pembelajaran bahasa Indonesia di SD pada dasarnya mempunyai maksud dan tujuan yang sama yaitu mengembangkan keempat aspek keterampilan berbahasa tersebut. Pada setiap keterampilan berbahasa mempunyai keterkaitan yang sangat erat antara satu dengan yang lain. Dalam memperoleh keterampilan berbahasa biasanya melalui suatu hubungan yang berurutan dan teratur, mula-mula dengan belajar menyimak atau mendengarkan bahasa, kemudian berbicara, sesudah itu belajar membaca dan menulis. Menyimak dan berbicara biasanya dipelajari sebelum memasuki bangku sekolah, sedangkan membaca dan menulis dipelajari setelah memasuki bangku sekolah. Keempat keterampilan tersebut pada dasarnya merupakan satu kesatuan atau merupakan catur tunggal,

Kaitannya
pembelajaran di sekolah dasar,
pelajaran Bahasa dan Sastra Indonesia
meliputi aspek kemampuan berbahasa
dan kemampuan bersastra. Aspek
kemampuan berbahasa meliputi
keterampilan mendengarkan
(menyimak), berbicara, membaca,
dan menulis yang berkaitan dengan


ragam bahasa non sastra. Sedangkan aspek kemampuan bersastra meliputi keterampilan mendengarkan (menyimak), berbicara, membaca, dan menulis yang berkaitan dengan ragam sastra.

Pembelajaran Bahasa

Indonesia haruslah lebih berkembang, tidak hanya terfokus pada kebiasaan dengan strategi atau urutan penyajian sebagai berikut: diajarkan definisi, diberikan contoh-contoh dan diberikan latihan soal. Hal ini sangat memungkinkan siswa mengalami kesulitan dalam menerima konsep yang tidak berasosiasi dengan pengalaman sebelumnya. Dalam latihan soal sebaiknya dihadapi bentuk soal cerita yang mungkin terkait dengan terapan bahasa Indonesia atau kehidupan sehari-hari.

Berdasarkan hasil pengamatan di kelas VI SD Negeri No 053979 Kepala Sungai Kecamatan Stabat Kabupaten Langkat Tahun Ajaran 2016/2017 permasalahan yang terjadi adalah :

1. Hasil belajar materi mendengarkan penjelasan tentang petunjuk denah dalam pembelajaran Bahasa Indonesia rendah.

2. Siswa tidak memiliki motivasi dalam berprestasi di sekolah.

3. Siswa tidak memahami penyampaian yang diterapkan oleh guru.

4. Siswa ribut di kelas saat pembelajaran berlangsung.
5. Ketika guru memberikan tugas, banyak siswa yang tidak mampu menyelesaikan tepat waktu.

6. Sebagai guru kelas, saya menyadari banyak kekurangan didalam pembelajaran sehingga berdampak pada pembelajaran.

Untuk mengatasi hal tersebut perlu diupayakan langkah-langkah yang dapat dilaksanakan baik oleh siswa maupun guru. Guru hendaknya mengemas proses belajar mengajar dengan model yang tepat dan menarik dalam penyajiannya. Salah satu model pembelajaran yang saya pilih adalah model pembelajaran Example Non Example. Dengan pembelajaran ini maka kegiatan belajar akan semakin efektif.

Konsep model pembelajaran ini pada umumnya dipelajari melalui dua cara. Paling banyak konsep yang kita pelajari di luar sekolah melalui pengamatan dan juga dipelajari melalui definisi konsep itu sendiri. Example Non Examples adalah taktik yang dapat digunakan untuk mengajarkan definisi konsep. Taktik ini bertujuan untuk mempersiapkan siswa secara cepat dengan menggunakan 2 hal yang terdiri dari example dan non-examples dari suatu definisi konsep yang ada, dan meminta siswa untuk mengklasifikasikan keduanya sesuai dengan konsep yang ada. Example memberikan gambaran akan sesuatu yang menjadi contoh akan suatu materi yang sedang dibahas, sedangkan non-examples memberikan 
gambaran akan sesuatu yang bukanlah contoh dari suatu materi yang sedang dibahas. Dengan memusatkan perhatian siswa terhadap example dan non-example diharapkan akan dapat mendorong siswa untuk menuju pemahaman yang lebih dalam mengenai materi yang ada.

Adapun yang menjadi tujuan dalam penelitian ini adalah: "untuk mengetahui apakah Model Pembelajaran Example Non Example meningkatkan hasil belajar siswa pada mata pelajaran Bahasa Indonesia di kelas VI SD Negeri No 053979 Kepala Sungai Tahun Ajaran 2016/2017".

\section{METODE PENELITIAN}

Metode yang digunakan dalam penelitian ini adalah Clasroom Action Research atau Penelitian Tindakan Kelas (PTK) dengan menggunakan Model Pembelajaran Example Non Example. Menurut Suharsimi Arikunto (2007:74) bahwa PTK terdiri atas rangkaian empat kegiatan yang dilakukan dalam siklus berulang. Empat kegiatan utama yang ada pada setiap siklus yaitu, perencanaan (planing), pelaksanaan (acting), Pengamatan (observing), dan refleksi (reflecting).

Penelitian ini dilakukan di kelas VI SD Negeri No 053979 Kepala Sungai Kecamatan Stabat Kabupaten Langkat Tahun Ajaran 2016/2017.

\section{HASIL DAN PEMBAHASAN}

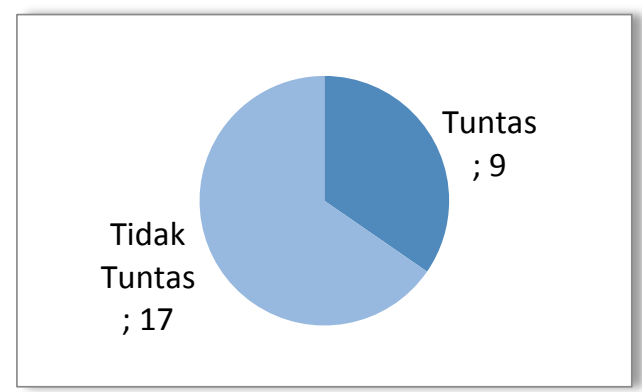

Gambar. Diagram Data Awal

Berdasarkan deskripsi hasil data awal materi mendengarkan penjelasan tentang petunjuk denah pada pelajaran Bahasa Indonesia di atas, dapat dilihat bahwa hasil belajar siswa dalam materi mendengarkan penjelasan tentang petunjuk denah masih rendah. Dari 26 orang siswa yang menjadi subjek dalam penelitian ini, ternyata hanya 9 orang siswa $(34,61 \%)$ yang sudah memiliki ketuntasan belajar, sedangkan selebihnya yaitu 17 orang siswa $(65,38 \%)$ belum memiliki ketuntasan belajar. Nilai rata - rata yang diperoleh hanya mencapai 65,63.

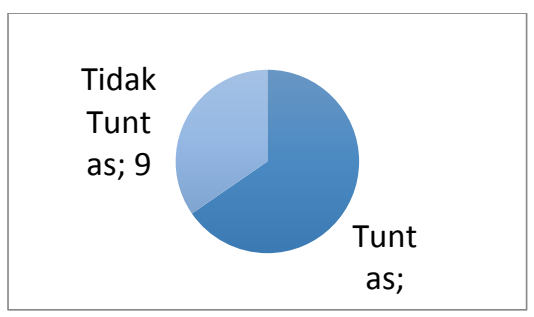

Gambar. Diagram Siklus I

Dari hasil analisa data siklus I siswa yang tidak tuntas sebanyak 9 orang dan yang tuntas sebanyak 17 orang, dapat disimpulkan bahwa hasil belajar siswa dari tes I masih rendah. 
Pada siklus ini guru menemukan beberapa kesulitan. Untuk itu maka perlu perbaikan tindakan untuk siklus II.

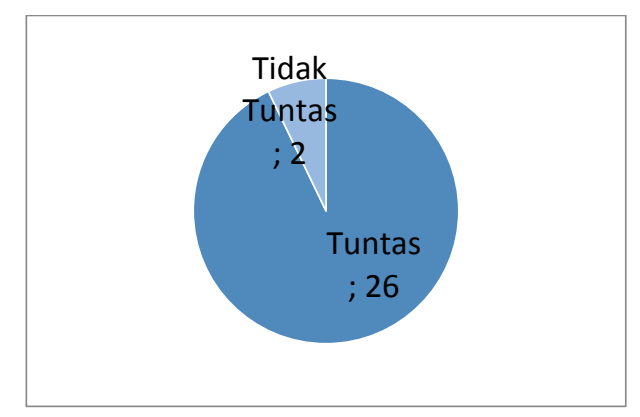

\section{Gambar. Diagram Siklus II}

Dari perkembangan siklus I dan sikus II dapat dilihat terjadi peningkatan hasil belajar secara individual maupun klasikal telah tercapai. Pada test hasil belajar I terdapat 65,38\%, siswa yang mencapai ketuntasan belajar. Pada tes hasil belajar II terdapat 92,30\%, siswa yang mencapai ketuntasan belajar dan terjadi peningkatan sehingga dapat disimpulkan pembelajaran materi menjelaskan tentang petunjuk denah pada pelajaran Bahasa Indonesia dengan menerapkan model yang dituangkan pada tes prestasi belajar I dan II mengalami peningkatan hasil belajar baik secara individu maupun klasikal.

Dari analisis data yang telah dilakukan dapat disimpulkan bahwasannya dengan menggunakan model Example Non Example dapat memberikan pengaruh serta meningkatkan kemampuan siswa pada materi menjelaskan tentang petunjuk denah pada pelajaran Bahasa
Indonesia. Dimana terlihat prestasi belajar siswa dari test hasil belajar I dapat meningkatkan hasil belajar siswa pada pokok bahasan menjelaskan tentang petunjuk denah pada pelajaran Bahasa Indonesia. Untuk selanjutnya perlu diadakannya perbaikan tindakan pada siklus II.

Pada siklus I guru menemukan banyak kesulitan yang dialami siswa dalam pembelajaran diantaranya :

1. Masih banyak kesalahan yang terjadi pada saat tes dilakukan.

2. Siswa tidak mengulangi pembelajaran yang telah diberikan.

3. Siswa kurang aktif dalam pembelajaran dikelas. Untuk mengatasinya guru memberikan motivasi kepada siswa agar mereka mau melakukan latihan mandiri.

Kemudian pada pembelajaran disiklus II dapat dilihat bahwa telah terjadi peningkatan aktivitas siswa dari siklus sebelumnya. Dari tes hasil analisis yang dilakukan disimpulkan bahwa telah terjadi peningkatan kemampuan siswa. Peningkatan ini terjadi setelah diberikan pembelajaran dengan menggunakan model Example Non Example yang lebih baik lagi yang dirancang pada siklus II yang beracuan pada refleksi dan pengalaman di siklus I. Pada tes hasil belajar II diperoleh hasil penelitian yaitu persentase nilai rata-rata setelah dikonversi sebesar 81,19 serta tingkat ketuntasan belajar klasikal siswa sebesar $92,30 \%$. Ini berarti terlihat 
ada peningkatan dari siklus ke siklus. Siklus II didapat hasil bahwa kriteria ketuntasan belajar secara klasikal yang diharapkan telah tercapai.

Namun masih ada beberapa siswa yang belum memperoleh ketuntasan belajar perindividu walaupun nilai yang diperoleh sudah meningkat dibandingkan pada siklus I. Dan untuk memperbaiki masalah siswa tersebut dikembalikan kepada guru kelas untuk meningkatkan hasil belajar siswa tersebut.

Agar pelajaran Bahasa Indonesia dapat mencapai suatu keberhasilan dan sasaran yang tepat, sebagai seorang guru harus bisa memilih dan merencanakan model yang akan digunakan dalam menyampaikan dan memecahkan berbagai masalah pendidikan. Dalam pembelajaran Bahasa Indonesia diperlukan suatu pemahaman terhadap materi-materinya pada siswa salah satunya dengan menggunakan suatu model pembelajaran. Konsep model pembelajaran ini pada umumnya dipelajari melalui dua cara. Paling banyak konsep yang kita pelajari di luar sekolah melalui pengamatan dan juga dipelajari melalui definisi konsep itu sendiri. Example Non Examples adalah taktik yang dapat digunakan untuk mengajarkan definisi konsep. Taktik ini bertujuan untuk mempersiapkan siswa secara cepat dengan menggunakan 2 hal yang terdiri dari example dan non-examples dari suatu definisi konsep yang ada, dan meminta siswa untuk mengklasifikasikan keduanya sesuai dengan konsep yang ada.

Berdasarkan deskripsi data penelitian, maka pada penelitian ini didapatkan hasil yaitu setelah pemberian tindakan pada siklus I sebanyak dua kali pertemuan, siswa diberikan tes hasil belajar I yang kemudian diperoleh dari 26 orang siswa yang menjadi subjek dalam penelitian ini, ternyata hanya 17 orang siswa $(65,38 \%)$ yang sudah memiliki ketuntasan belajar, sedangkan selebihnya yaitu 9 orang siswa $(34,61 \%)$ belum memiliki ketuntasan belajar. Nilai rata-rata yang diperoleh hanya mencapai 68,4 namun belum memenuhi kriteria ketuntasan secara klasikal yang diharapkan yaitu $85 \%$. Dikarenakan ada beberapa faktor siswa tersebut belum bisa mencapai tingkat ketuntasan belajar yaitu kurang pahamnya siswa bagaimana mengerjakan soal materi menjelaskan tentang petunjuk denah dengan benar pada pelajaran Bahasa Indonesia.

Kemudian setelah diberikan tindakan pada siklus II sebanyak dua kali pertemuan, siswa kembali diberi test hasil belajar II yang kemudian diperoleh ternyata 24 orang siswa $(92,30 \%)$ yang sudah memiliki ketuntasan belajar, sedangkan selebihnya yaitu 2 orang siswa $(7,69 \%)$ belum memiliki ketuntasan belajar. Nilai rata-rata yang diperoleh hanya mencapai 81,19. 
Example memberikan gambaran akan sesuatu yang menjadi contoh akan suatu materi yang sedang dibahas, sedangkan non-Examples memberikan gambaran akan sesuatu yang bukanlah contoh dari suatu materi yang sedang dibahas. Dengan memusatkan perhatian siswa terhadap example dan non-example ternyata dapat mendorong siswa untuk menuju pemahaman yang lebih dalam mengenai materi yang ada. Berdasarkan hal ini, maka yang menjadi kesimpulan dalam penelitian tindakan kelas ini adalah "Terdapat Peningkatkan Hasil Belajar Siswa Pada Mata Pelajaran Bahasa Indonesia Melalui Model Pembelajaran Example Non Example Di Kelas VI SD Negeri No 053979 Kepala Sungai Kabupaten Langkat T.A. 2016/2017”.

\section{SIMPULAN}

Tes hasil belajar I yang kemudian diperoleh dari 27 orang siswa yang menjadi subjek dalam penelitian ini, ternyata hanya 17 orang siswa $(62,96 \%)$ yang sudah memiliki ketuntasan belajar, sedangkan selebihnya yaitu 10 orang siswa $(37,04 \%)$ belum memiliki ketuntasan belajar. Nilai rata-rata yang diperoleh hanya mencapai 68,4 . Kemudian setelah diberikan tindakan pada siklus II sebanyak dua kali pertemuan, siswa kembali diberi test hasil belajar II yang kemudian diperoleh ternyata 24 orang siswa $(88,88 \%)$ yang sudah memiliki ketuntasan belajar, sedangkan selebihnya yaitu 3 orang siswa $(11,12 \%)$ belum memiliki ketuntasan belajar.

Nilai rata-rata yang diperoleh hanya mencapai 81,19. Dengan memusatkan perhatian siswa terhadap example dan non-example ternyata dapat mendorong siswa untuk menuju pemahaman yang lebih dalam mengenai materi yang ada. Berdasarkan hal ini, maka yang menjadi kesimpulan dalam penelitian tindakan kelas ini adalah "Terdapat Peningkatkan Hasil Belajar Siswa Pada Mata Pelajaran Bahasa Indonesia Melalui Model Pembelajaran Example Non Example Di Kelas IV B SD Negeri No. 058107 Sei Dendang Kecamatan Stabat Kabupaten Langkat T.A. 2015/2016".

\section{DAFTAR RUJUKAN}

Agus, Suprijono. (2009). Cooperative Learning Teori dan Aplikasi PAIKEM. Yogyakarta: Pustaka Pelajar.

Aminuddin. (1994). Pembelajaran Terpadu Sebagai Bentuk Penerapan Kurikulum 1994 Mata Pelajaran Bahasa Dan Sastra Indonesia. Malang: Vokal. Telaah Bahasa Dan Sastra.

Annurahman. (2012). Belajar dan Pembelajaran. Bandung: Alfabeta

Dimyati \& Mudjiono, (2006). Belajar dan Pembelajaran. Jakarta: Rineka Cipta. 
Gilstrap R. L And Martin W. R. (1975). Current Strategies For Teacher. California, Santa Monica: Goodyear Publishing Company Inc.

Hamalik, Oemar. (2010). Kurikulum dan Pembelajaran. Jakarta; Bumi Aksara.

Hamdani. (2011). Strategi Belajar Mengajar. Bandung: Pustaka Setia.

Hamzah. B. Uno (2007). Model Pembelajaran (Menciptakan Proses Belajar Mengajar Yang Kreatif dan Efektif). Jakarta: Bumi Aksara.

Ibrahim. (2000). Pembelajaran Kooperatif. Surabaya: UNESA-University Press.

Istarani (2011). 58 Model Pembelajaran Inovatif. Medan: Media Persada.

Nur, M. dan Wikandari, P.R. (2000). Pengajaran Berpusat kepada Siswa dan Pendekatan Konstruktivistik dalam Pengajaran. Surabaya: Universitas Negeri Surabaya.
Ridwan Abdul Sani (2013). Inovasi Pembelajaran. Jakarta: Bumi Aksara.

Rosmala Dewi (2010). Penelitian Tindakan Kelas. Medan: Pascasarjana Unimed.

Sudjana, Nana. (2010). Penilaian

$\begin{array}{lrr}\text { Hasil } & \text { Proses } & \text { Belajar } \\ \text { Mengajar. } & \text { (Cet. } & X V \text { ). } \\ \text { Bandung: } & \text { PT. } & \text { Ramaja } \\ \text { Rosdakarya. } & & \end{array}$

Suharsimi Arikunto. (2010). Penelitian Tindakan Kelas. Jakarta: Rineka Cipta.

Suyatno. (2009). Menjelajah Pembelajaran Inovatif, Sidoarjo: Masmedia Buana Pustaka.

Wahidmurni. (2010). Evaluasi Pembelajaran Kopetensi Dan Praktik. Yogyakarta: Nuha Litera.

Wina Sanjaya (2011). Strategi Pembelajaran Berorientasi Standard Proses Pendidikan. Bandung: Kencana Prenada Media. 